\title{
ACTIVE LABOUR MARKET POLICIES IN ECONOMIES BASED ON TOURISM: THE BALEARIC ISLANDS EXPERIENCE ${ }^{1}$
}

\author{
Francisco Caparros Alcaraz
}

Servei d'Ocupació de les Illes Balears

\begin{abstract}
Balearic Islands are a European-leading destination but the economic specialization in tourism activities produce dysfunctionalities in the labour market such as seasonality, a high demand of human resources in a short period, low level of educational attainment and underemployment. As counterpart, Active Labour Market Policies (ALMPs) are a set of interventions aimed to enhance human capital and to smooth career transitions. The aim of this paper is to shed light on these issues. Results suggest that Balearic Islands Employment Service (SOIB) is focused on counselling and training while other policies are not properly developed.
\end{abstract}

Keywords: tourism, labour market, Balearic Islands, Employment Services, guidance, counselling, training, entrepreneurship, job search assistance, ALMPs, PES.

\section{Mercado de trabajo y políticas activas de empleo en economías basadas en turismo: la experiencia de las Islas Baleares}

\section{RESUMEN}

Las Islas Baleares son un destino líder en Europa, pero la especialización económica en actividades turísticas produce disfuncionalidades en el mercado de trabajo como la estacionalidad, una elevada demanda de recursos humanos en periodos cortos, niveles bajos de cualificación y subempleo. Por otro lado, las Políticas Activas de Empleo son un

Recibido: 17 de mayo de 2016

Devuelto para su revisión: 21 de noviembre de 2016

Aceptado: 20 de diciembre de 2016

Servei d'Ocupació de les Illes Balears. Camí Vell de Bunyola, 43. 07009 PALMA DE MALLORCA (España).E-mail: fjcaparros@soib.caib.es.

1 The paper is a summary of the research required for obtaining the Master degree in Applied Labour Economics for development awarded by the International Training Centre of the International Labour Organization (ITCILO), the University of Torino (Unito) and the Institut d'Etudes Politiques de Paris (Science Po). The author thanks SOIB for support. 
conjunto de intervenciones dirigidas a mejorar el capital humano y a suavizar las transiciones de carrera profesional. El objetivo del artículo es arrojar luz sobre estas cuestiones. Los resultados sugieren que el Servicio de Empleo de las Islas Baleares (SOIB) se centra en la orientación y la formación, mientras que otras opciones no se desarrollan adecuadamente.

Palabras clave: turismo, mercado de trabajo, Islas Baleares, Servicios de empleo, orientación, formación, emprendimiento, intermediación laboral, PAE, SOIB.

\section{INTRODUCTION}

Over last decades, Balearic Islands have experienced a continued economic growth and deepening into tourism services and product diversification until become the most important economic output (Manera et al. 2016). Such dynamics are highly demanding on quantity of human resources required and configure an idiosyncratic labour market with some weaknesses such as low rates of investment in $\mathrm{R}+\mathrm{D}$, basic level of educational attainment, microenterprises structure and seasonality due the sharpened transitions between employment and unemployment during the summer and winter season. A detailed comparative diagnosis of major issues is presented in chapter two.

On the other hand, SOIB is the public administration responsible of executing active labour market policies (ALMPs) in Balearic Islands. The aim is to tackle disequilibria and facilitate career transitions between employment and unemployment at regional scope. Chapter three presents the ALMPs empirical review. It is described what works and why in advanced economies and considers some issues produced by tourism activities before chapter four goes in a description of SOIB activities and the policy options to address labour market weaknesses produced by tourism.

The core part of the paper regards in the systematic review of all ALMPs designed, executed and monitored by SOIB. The results and preliminary conclusions are presented in chapter five. The facts analysed are unemployment, labour contracts, job searching assistance, management of vacancies, counselling, guidance, vocational education training, dual training, public employment programmes, wage subsidies, and entrepreneurial assistance. Finally, chapters six and seven are aimed to give policy advices taking into account the Balearic Islands labour market and the ALMPs executed by SOIB.

Last but not least, we believe that the paper presented is valuable because it focuses on the problems that usually face any highly specialized economy on tourism and how ALMPs attempt to address the chiaroscuro of a labour market affected by seasonal economy.

\section{BALEARIC ISLANDS LABOUR MARKET}

Balearic Islands (NUTS 2) ${ }^{2}$ are one of the seventeen Autonomous Communities of the Spanish Kingdom and consequently are part of the European Union. The archipelago is

2 Eurostat (Eurostat, 2014) promotes the use of the Nomenclature of Territorial Units for Statistics (NUTS). The Spanish kingdom (ES) is one of the 28 States of the EU (NUTS 0). The East of Spain (ES5) is major socio-economic region (NUTS1) which includes Catalonia, Balearic Islands and Valencia. The Balearic Islands 
located in the Western Mediterranean sea and it is formed by four inhabited islands, small islands and several islets. Land is $4,992 \mathrm{~km}^{2}$ and the largest islands are Majorca, Minorca, Ibiza and Formentera.

\subsection{Demographic evolution}

The Balearic Islands population is 1,103,442 (INE, 2015) and population density is $221 / \mathrm{km}^{2}$. The last years the population is decreasing due to the fall down of foreigners (Govern Illes Balears, 2015).

\section{Graph 1 \\ EVOLUTION BALEARIC ISLANDS POPULATION}

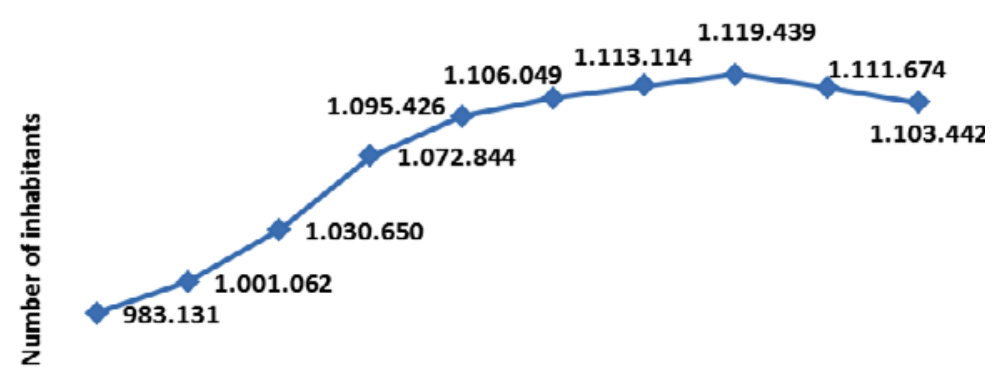

\begin{tabular}{|cccccccccc|}
\hline 2005 & 2006 & 2007 & 2008 & 2009 & 2010 & 2011 & 2012 & 2013 & 2014 \\
& \multicolumn{1}{c|}{ Years } \\
\hline
\end{tabular}

Source: INE.

The territorial distribution of the population shows that Majorca with 858,313 people is the most populated Island, followed by Ibiza 140,271, Minorca 93,313 and Formentera with 11,545 inhabitants.

Balearic Islands show no significant differences between male and female $(\mathrm{p}<0.001)$. The working age population is $69.56 \%$. However, some risks can be observed in the long run due the evolution of the Dependency ratio which has been increased until $43.74 \%$ in 2014. The Dependency ratio explains the pressure of those under the age of 15 and over 64 to the productive or working age population.

(ES53) is a basic region (NUTS 2) designed for regional policies but further disintegration by Islands (NUTS 3) can be done as Majorca (ES532), Minorca (ES533) Ibiza and Formentera (ES531) for local policies. This will be the territorial structure used along the study. 
Graph 2

POPULATION DISTRIBUTIONS BY ISLANDS IN 2014

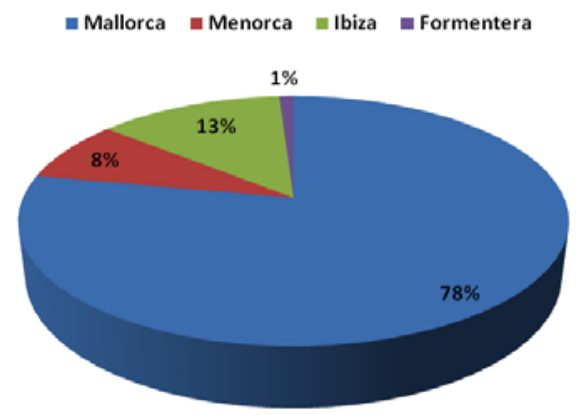

Source: Annual Census (INE).

Table 1

Table 2

\section{POPULATION DISTRIBUTED BY POPULATION DISTRIBUTED BY AGE GENDER}

\begin{tabular}{|c|r|}
\hline GENDER & POPULATION \\
\hline MALE & 549,801 \\
\hline FEMALE & 553,641 \\
\hline
\end{tabular}

Source: Annual Census (INE).

\begin{tabular}{|r|r|}
\hline \multicolumn{1}{|c|}{ AGE } & POPULATION \\
\hline $0-14$ & 172,250 \\
\hline $15-64$ & 767,603 \\
\hline$>64$ & 163,589 \\
\hline
\end{tabular}

Source: Annual Census (INE).

\section{Graph 3}

POPULATION PYRAMID IN 2014

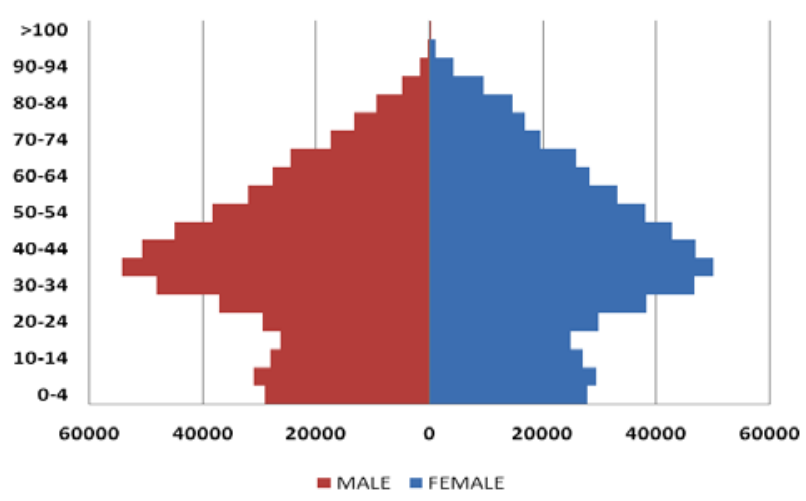

Source: author from Annual Census (INE). 
The Balearic Islands population pyramid is regressive. It is wider at the top than at the base, due to falling birth rates and the continued aging of the population; therefore, future prospects are declining.

\section{Graph 4}

POPULATION AGED 25-64 WITH TERTIARY EDUCATIONAL ATTAINMENT

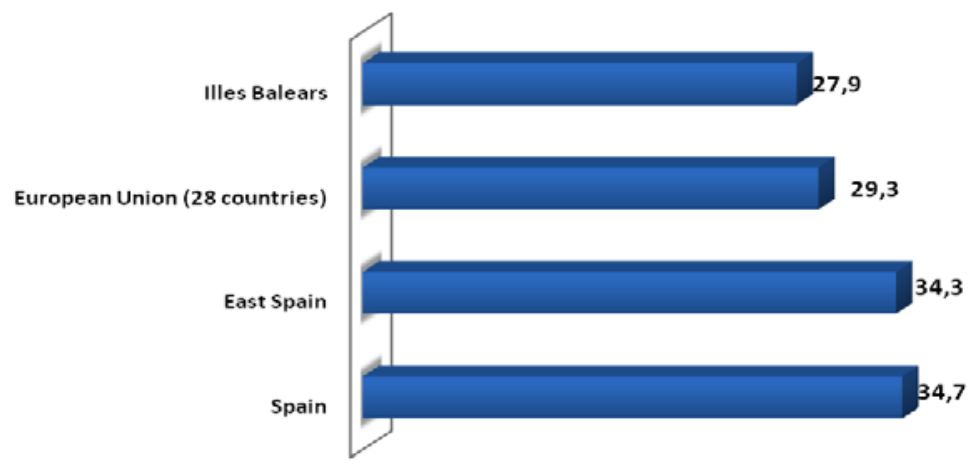

Source: Eurostat.

\section{Graph 5 \\ EARLY LEAVERS FROM EDUCATION AND TRAINING IN 2014}

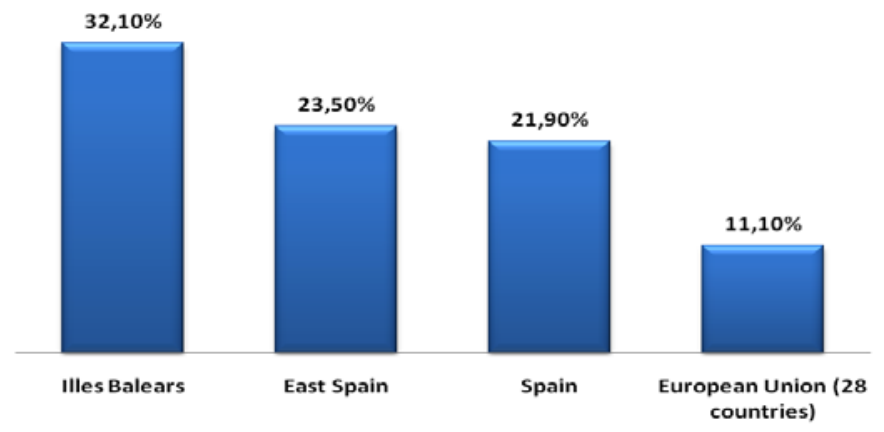

Source Eurostat.

Balearic Islands have the lowest rate of population with tertiary educational level $(27.9 \%)$ if it is compared with the European Union, Spain and the East Spain which is the territory that includes Balearic Islands, Catalonia and Valencia because these regions have strong relationships in demography, education, economy and natural resources. Indeed, Balearic Islands have one of the highest rates of early leavers from education and training $(32.1 \%)$ in the European Union. Such rates evidence a lack of skills in the workforce. One reason is the accessibility to low qualified employment in tourism activities during the summer season that are acting as a disincentive to the long life learning. 


\subsection{Economic evolution}

From 2014, the Spanish economy is recovering from both the global financial crisis of 2008 and the sovereign debt crisis that affected the country in 2011 (ILO, 2014). The Balearic Islands economy is one of the most dynamic European regions in terms of economic growth. The gross domestic product (GDP) growth rate estimated for the third quarter 2015 is $2.8 \%$ (Govern Illes Balears, 2015). In fact, Balearic Islands perform smoothly in the long run with less expansive or contractive economic peaks than European Union and Spain.

Furthermore, the evolution of the gross value added (GVA) at basic prices from 2009 to 2013 shows a pronounced negative pattern in Spain $(-4.7 \%)$ and also in the East of Spain $(-4.8 \%)$ while Balearic Islands is less adverse $(-1.5 \%)$ during the worst years of the crisis. It is considered that the reason of this damping is the high specialization of the economy in tourism activities oriented to international markets which are not affected by internal demand crisis.

\section{Graph 6 \\ REAL GDP GROWTH RATE}

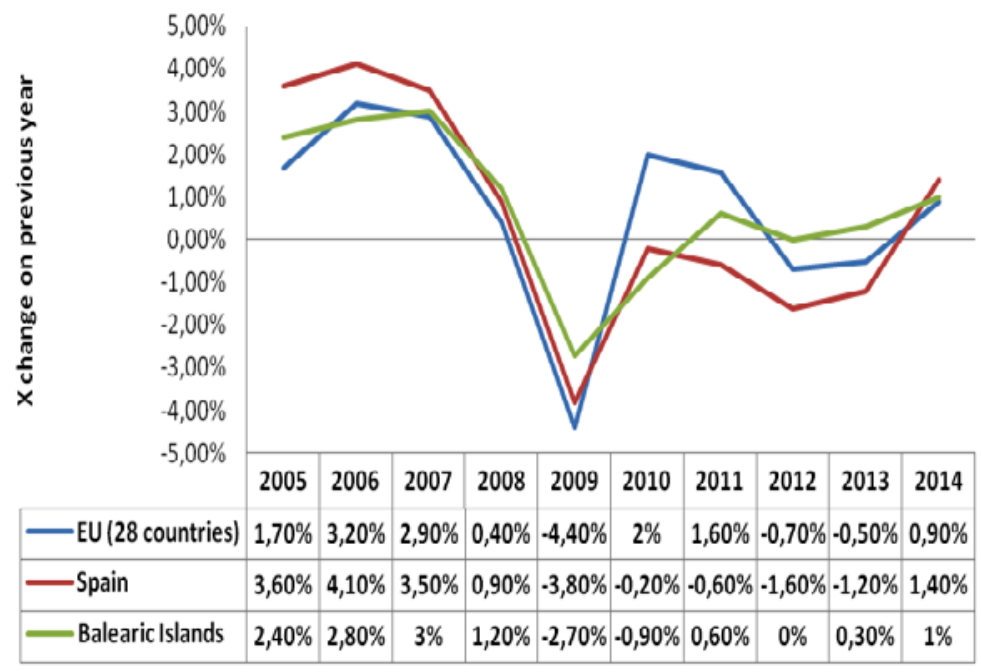

Sources: Eurostat and Govern Illes Balears.

The different contribution of the economic activities as well as their aggregation by economic sectors shows that Balearic Islands depend on Services $(86.17 \%)$ more than Industry, Construction or Agriculture. A detailed analysis indicates that many economic activities are clearly linked to tourism dynamics such as Accommodation, food, trade (36\%), Real Estate (16.68\%) or Entertainment (4.78\%). 


\section{Graph 7 \\ ECONOMIC SECTORS 2014}

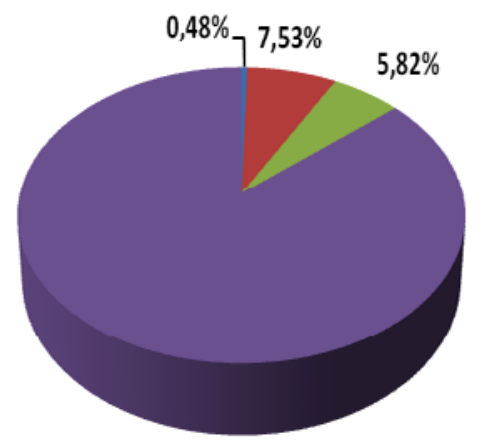

- Agriculture, forestry

and fishing

Industry

- Construction

@Services

$86,17 \%$

Graph 8

GROSS VALUE ADDED AT BASIC PRICES IN 2013

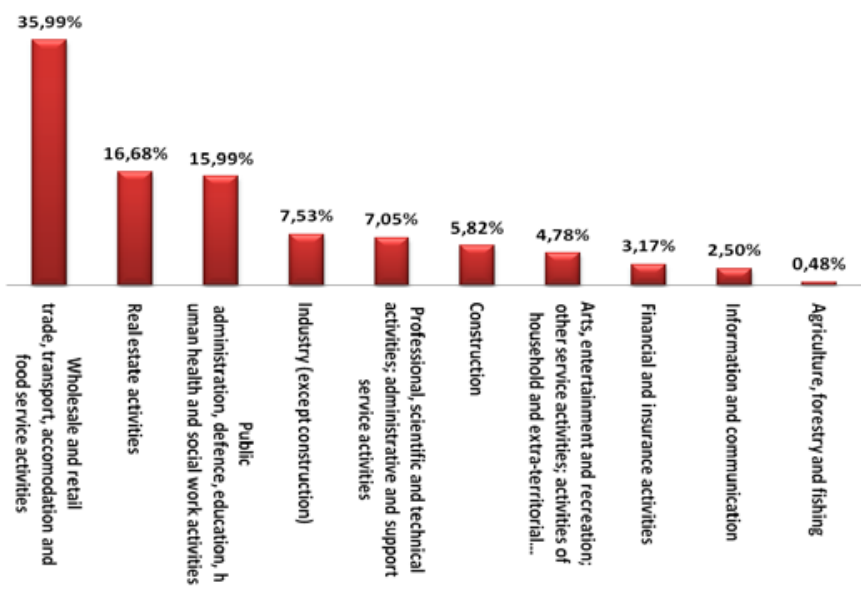

Source: Eurostat NACE Activities.

\subsection{Enterprises structure}

The study follows the definition of micro, small, medium-sized and large enterprises recommended by the European Union. The enterprises are defined according to their staff headcount and turnover or annual balance-sheet total (European Commission, 2003). Microenterprise is an enterprise which employs fewer than 10 persons and whose annual turnover and/or annual balance sheet total does not exceed EUR 2 million. Small enter- 
prise is an enterprise which employs fewer than 50 persons and whose annual turnover and/or annual balance sheet total does not exceed EUR 10 million. Medium-sized enterprise is an enterprise which employs fewer than 250 persons and whose annual turnover does not exceed EUR 50 million or whose annual balance-sheet total does not exceed EUR 43 million. Large enterprise is an enterprise not included in previous categories. Large enterprise employs more than 250 persons and its annual turnover and/or balance-sheet exceed EUR 43 million.

Table 3

BALEARIC ISLANDS ENTERPRISES BY SIZE IN 2014

\begin{tabular}{|l|r|r|}
\hline & \multicolumn{1}{|c|}{ TOTAL } & \multicolumn{1}{c|}{$\%$} \\
\hline MICRO ENTERPRISES & 81,038 & $96.16 \%$ \\
\cline { 2 - 3 } SMALL ENTERPRISES & 2,734 & $3.24 \%$ \\
\cline { 2 - 3 } MEDIUM ENTERPRISES & 436 & $0.52 \%$ \\
\cline { 2 - 3 } LARGE ENTERPRISES & 62 & $0.07 \%$ \\
\hline TOTAL & $\mathbf{8 4 , 2 7 0}$ & $\mathbf{1 0 0 \%}$ \\
\hline
\end{tabular}

Source: Spanish Central Business Directory.

Graph 9

COMPANIES BY EMPLOYEES STRATUM IN 2014

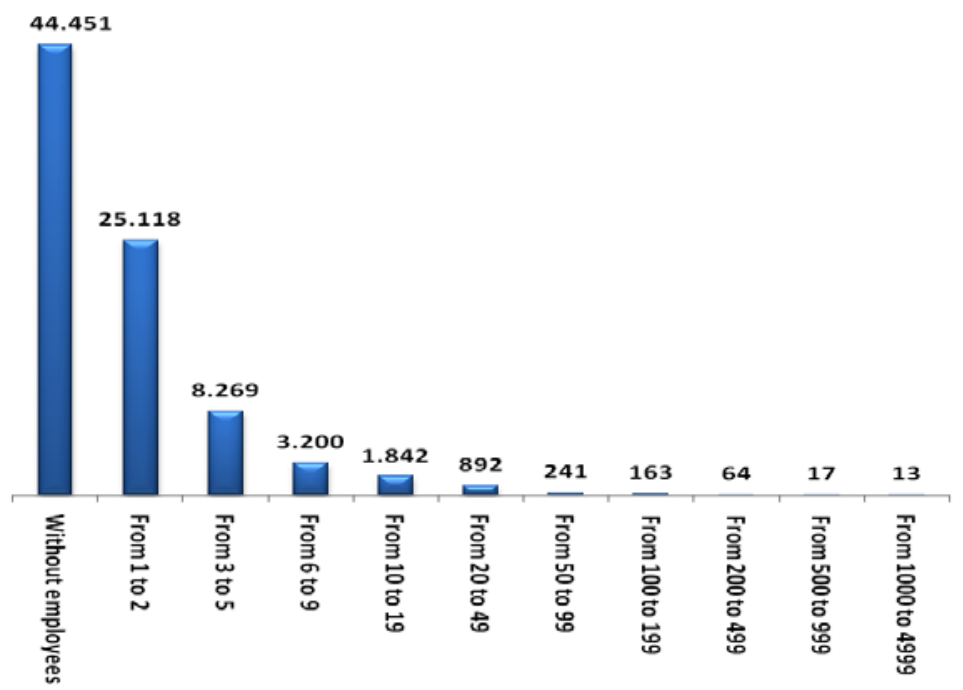

Source: Spanish Central Business Directory. 
The business structure of Balearic Islands is characterized by microenterprises $(96.16 \%)$ which mean less than 10 employees and an annual balance-sheet under EUR 2 million. In fact, even companies with no salaried worker already account half (52.75\%) of total enterprises. Such fragmentation into micro and small enterprises affects labour demand and supply by promoting individual relationships between employer and employee. This also discourages further training due the lack of executive or management positions. On the other hand, the employee stratum indicates that people try to be entrepreneur and run their own business in the Balearic Islands. Most common enterprise-size is self-employed without employers $(44,451)$.

\subsection{Labour Market}

The working age population is 777,300 people and active population is 600,600 . One stylised fact is that females are participating more than years ago in the Balearic Islands labour market. The gender gap is being closed but it may be interpreted as a consequence of male unemployment in construction activities due the burst of the real estate bubble in 2007 and the maintenance of employment related with tourism activities which is highly feminised in low qualified jobs (Govern Illes Balears, 2015).

\section{Graph 10 \\ ECONOMICALLY ACTIVE POPULATION \\ BY SEX IN BALEARIC ISLANDS}

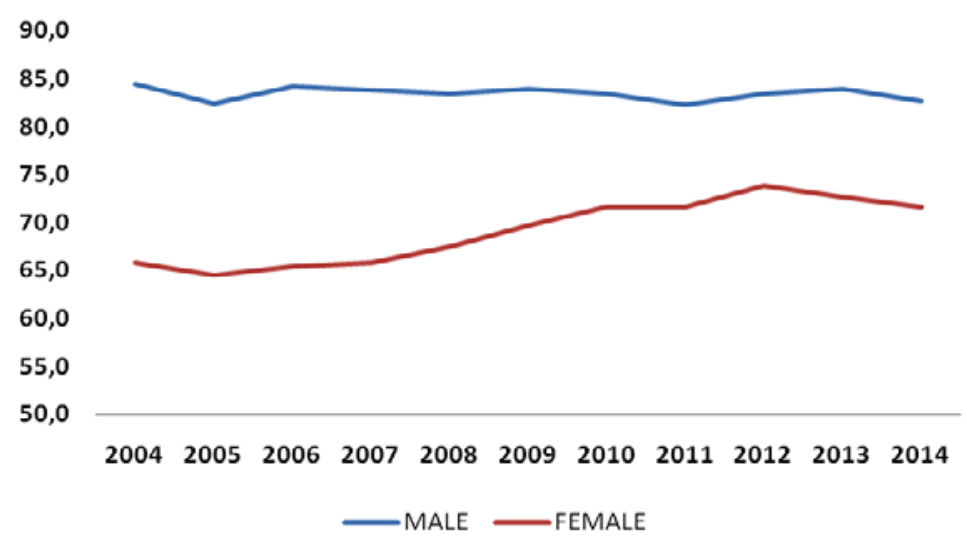

Source: Eurostat.

The employment/labour force rate in Balearic Islands decreased from $68.5 \%$ in 2004 to $61.8 \%$ in 2014 . However, data shows that Balearic Islands had performed better in the whole series than Spain and East Spain. In 2014, Spain employment/labour force rate $(56 \%)$, East Spain (59.2\%) and Balearic Islands $(61.8 \%)$ are below the EU rate $(64.8 \%)$. 


\section{Graph 11 \\ EMPLOYMENT RATE EVOLUTION COMPARISON BALEARIC ISLANDS, SPAIN, EAST SPAIN AND EU}

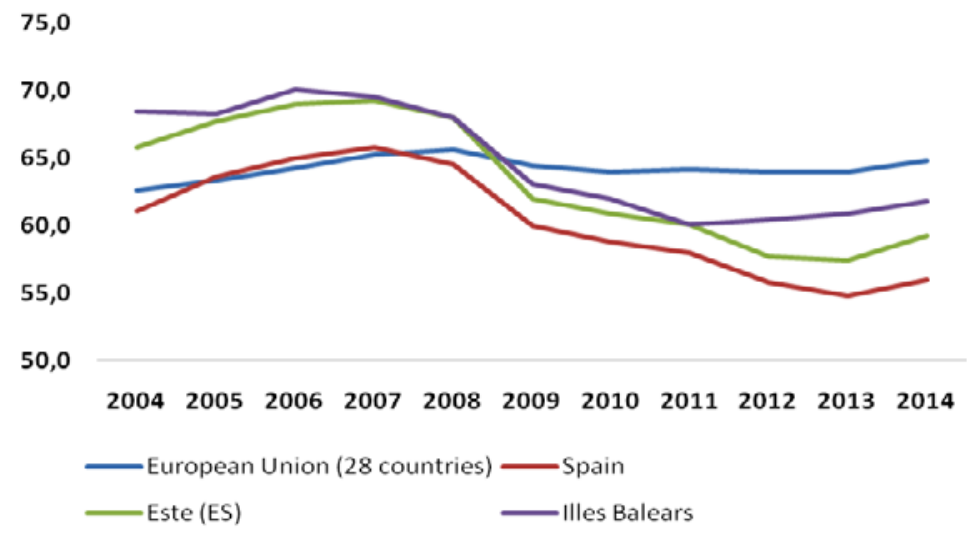

Source: Eurostat.

Graph 12

EMPLOYMENT RATE EVOLUTION BY SEX IN BALEARIC ISLANDS

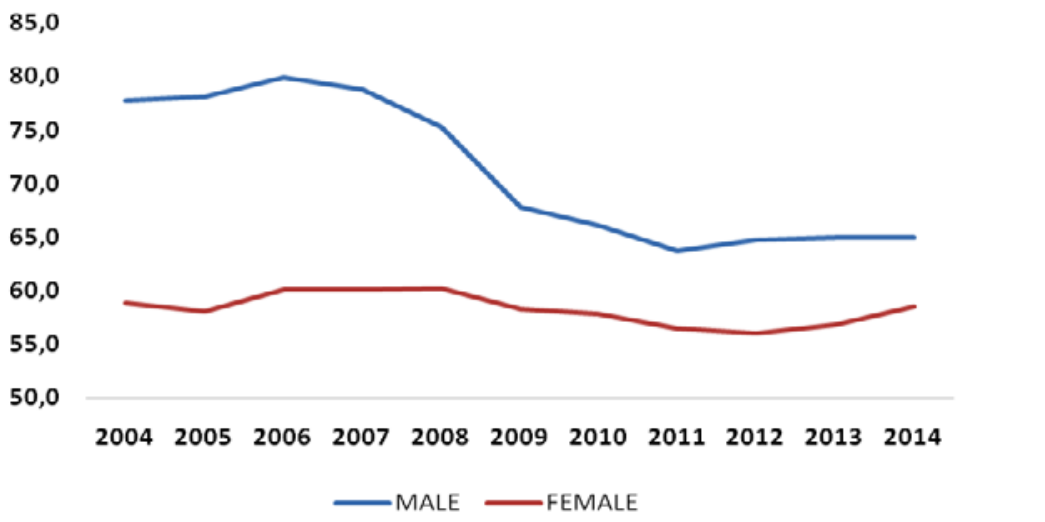

Source: Eurostat.

Females in Balearic Islands have lower employment rate than males. However, the gap is narrowing due the fact that the economical downturn affected more traditional male employments such as construction and industry than the employment with higher prevalence of women such as social services, health or education. 


\section{Graph 13 \\ EMPLOYMENT RATE BY ECONOMIC ACTIVITIES IN 2014}

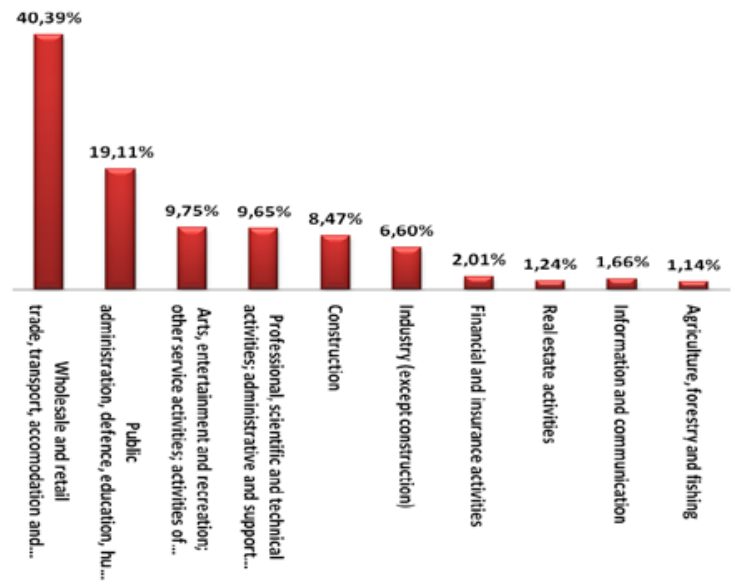

Source: Eurostat NACE actitivites

Some economic sectors hire more workers than others and special attention should be paid to wholesale, retail trade, food activities and accommodation (40.39\%), public services $(19.11 \%)$, entertainment $(9.75 \%)$ and professional and technical services $(9.65 \%)$. Results are in line with gross value added by economic activities -graph 6-. Such results indicate that Balearic Islands economy relies on a labour market specialized in services and tourism activities.

Graph 14

EMPLOYMENT RATE BY EDUCATION IN 2014

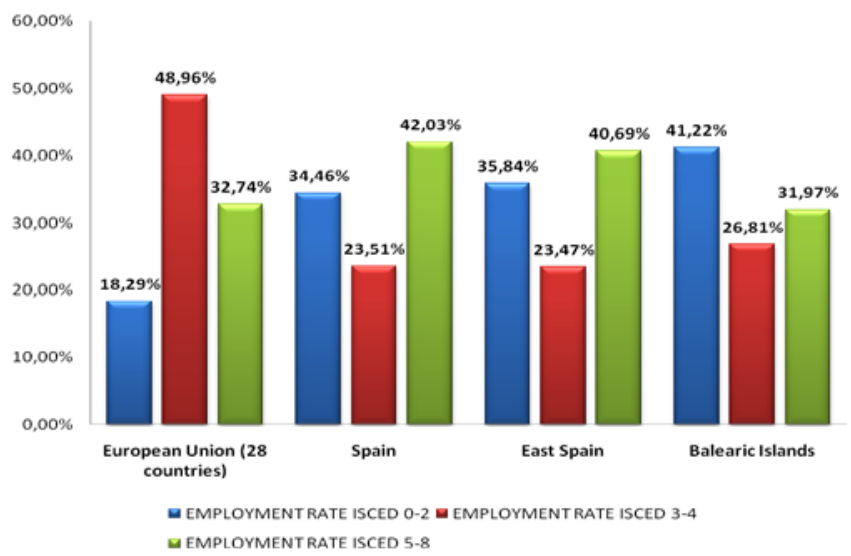

Source: Eurostat and International Standard Classification of Education -ISCED- 
The employment rates taking into account the educational attainment show that in EU the most employed category is Upper secondary and post-secondary non-tertiary education -ISCED 3 to 4- (49\%), followed by Tertiary education -ISCED 5 to 8(33\%). However, Spain (42\%) and East Spain (41\%) are employing more people with tertiary education attainment, followed by primary and lower secondary education -ISCED 0 to 2-. One possible reason is that economical crisis destroyed employment with low productivity which usually is associated with primary and secondary educational attainment. Another reason is a deep skills mismatch produced by an excess of labour market demand due the high unemployment rates. Consequently, labour market demand prefers high qualified workers to match vacancies that require less educational attainment (ILO, 2014).

Notwithstanding, Balearic Islands have a different pattern. The educational attainment most employed is less than primary and lower secondary education (41\%), followed by tertiary education (33\%). Such duality indicates that Balearic Islands economy mainly requires low qualified workers to match tourism employment offers that are highly demanding in terms of human resources as suggested in table 4 . This fact is another important disincentive to continue studying and training. Again, the tourism economic activities act as a gateway to the labour market but without investment in human capital.

Table 4

MOST FREQUENTS EMPLOYMENTS IN BALEARIC ISLANDS IN 2014

\begin{tabular}{|r|l|r|}
\hline \multicolumn{2}{|l|}{} & CONTRACTS \\
\hline 1 & Waiters and bartenders & $\mathbf{6 1 , 1 7 7}$ \\
3 & Cleaning staff offices and hotels & $\mathbf{3 3 , 9 5 1}$ \\
4 & Sales workers & $\mathbf{2 5 , 0 1 3}$ \\
5 & Kitchen assistents & $\mathbf{1 3 , 4 4 1}$ \\
6 & Chefs & $\mathbf{1 2 , 9 9 2}$ \\
7 & Bricklayers & $\mathbf{1 2 , 1 3 4}$ \\
8 & Administrative staff & $\mathbf{8 , 7 3 1}$ \\
9 & Domestic workers & $\mathbf{7 , 1 6 9}$ \\
10 & Composers, musicians and singers & $\mathbf{6 , 9 7 3}$ \\
\hline
\end{tabular}

Source: OTIB

On the other hand, the most frequent jobs in Balearic Islands can be a predictor of labour conditions. The employments with low skills requirements such as waiter, cleaning staff, kitchen assistants, or bricklayers are usually affected by temporality, partiality, low wages and general poor conditions. 


\section{Graph 15 \\ UNEMPLOYMENT RATE EVOLUTION (SEASONALLY ADJUSTED)}

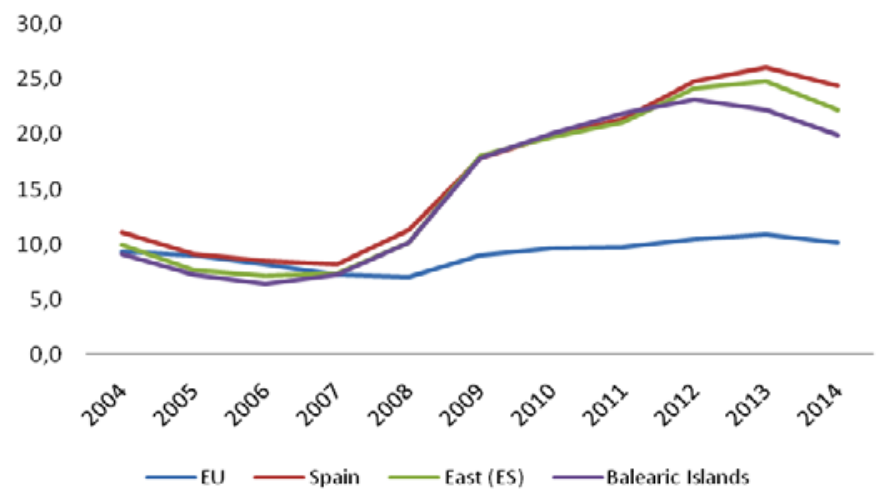

Source: Eurostat.

In 2014, the Balearic Islands unemployment rate seasonally adjusted (20\%) is lower than Spain $(24.4 \%)$ and East Spain $(22.2 \%)$ but almost two times higher than EU rate (10.2\%). Maybe there is an unemployment pattern in Europe based on economic activities and geographical elements more than country specificities because European southern regions from Spain, Greece, Italy or Croatia have higher unemployment than central or northern regions. A detailed analysis of economic activities shows that such regions are specialized in tourism services more than industrial ones (Eurostat, 2014).

\section{Graph 16}

\section{UNEMPLOYMENT RATE EVOLUTION BY SEX IN BALEARIC ISLANDS}

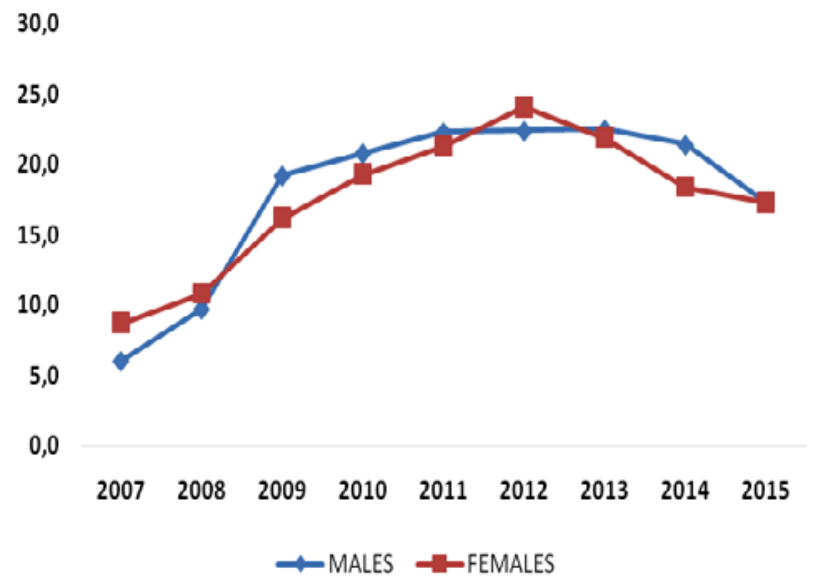

Source: Eurostat Labour Force Survey. 


\section{Graph 17 \\ UNEMPLOYMENT YOUTH RATE DISAGGREGATED BY SEX}

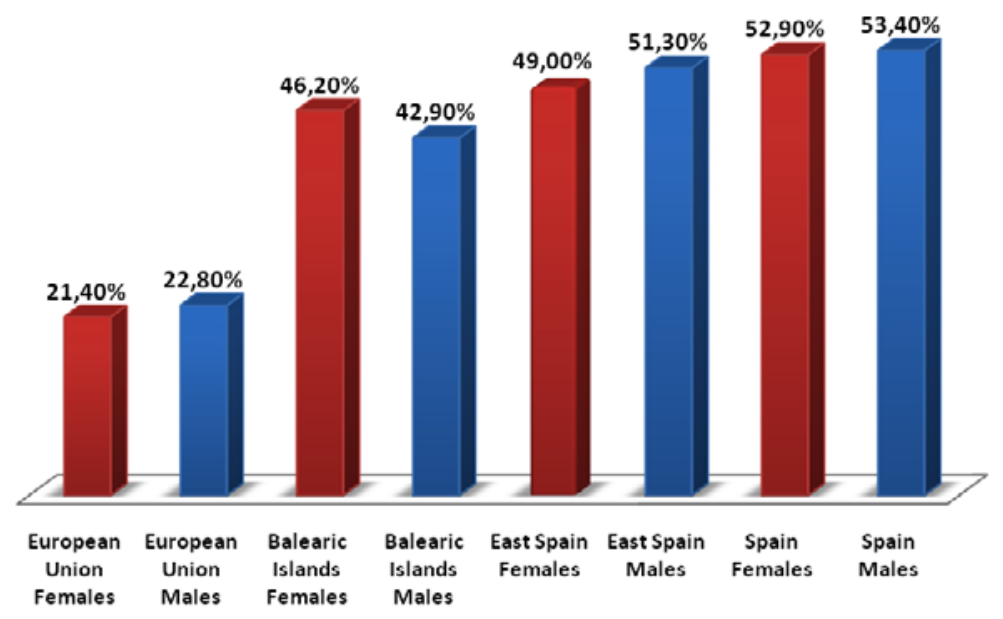

Source: Eurostat.

It is clear that the economical crisis rocketed the unemployment rate in Balearic Islands from $6 \%$ in 2006 to $23 \%$ in 2013. Apart from 2012, unemployment rates affected more male than female in the economic downturn data serie. Tourism activities has acted as a shock absorber in the labour market because many unemployed moved from construction and manufacturing activities to services (Govern de les Illes Balears, 2015)

An important issue is youth unemployment because arises as one of the most important challenges not only in the Balearic Islands but also in EU and the States members. The youth comprised between 15 to 24 years is facing a major problem due the lack of employment. The EU youth unemployment rate (22.1\%) is two times higher than EU unemployment rate $(10.4 \%)$. Such double youth unemployment rate or even worst is also happening in Spain (53.2\%), East Spain (50.2\%) and Balearic Islands (44.6\%) when youth unemployed rate is compared with their general unemployment rates; Spain (24.4\%), East Spain (22.2\%) and Balearic Islands (20\%).

The sex-disaggregated data show more youth males unemployed than females in EU $(22.8 \%)$, Spain $(53,4 \%)$ and East Spain $(51,3 \%)$. However, Balearic Islands have a different distribution because youth unemployed female rate $(46.2 \%)$ is higher than youth male rate $(42,9 \%)$.

As a conclusion, a regional approach and a gender mainstream should be considered to tackle youth unemployment and to promote education or training because many European economies based on services or industrial activities seem not able to integrate youth into the productive system. It is required to develop specific employment policies such as second-opportunity actions, apprenticeships or employment programmes addressed to young people. The youth guarantee scheme proposed by EU is a good chance to transform the youth panorama. 


\section{ALMPS EMPIRICAL EVIDENCE}

Labour market policies (LMPs) are public interventions in the labour market aimed at reaching its efficient functioning and correcting disequilibria and which can be distinguished from other general policy interventions in that they act selectively to favour unemployed, employed at-risk and inactive in the labour market (Eurostat, 2013). There is a general consensus in consider two major policies:

Passive labour market policies (PLMPs) which provide income replacement for those are unemployed to avoid social exclusion while they are looking for a new job.

Active labour market policies (ALMPs) which are a set of interventions aimed to improve the access of the unemployed to the labour market, job-related skills and the functioning of the labour market (Martin, 1998). Finally, both policies are linked by the mandatory activation principle in order to reduce the cost of unemployment benefits (Rosholm, 2014).

ALMPs such as job search assistance, training, wage subsidies, and direct job creation are a key element of European countries' efforts to combat unemployment (Kluve, 2010). These programmes are implemented to enhance labour supply -training-, increase labour demand -subsidies-, promote entrepreneurship and improve the functioning of labour markets thru public employment services (Betcherman et al. 2004).

However, ALMPs are not the magical solution in a context of high or seasonal unemployment and depressed labour demand. They may alleviate the symptoms (Lechner \& Wunsch, 2009) but not overcome the structural imbalances. A comprehensive strategy is convenient if public administrations want to readdress the matureness of tourist destinations focused on sun and beach (Salvà, 1998).

The convenience of assessing ALMPs becomes more relevant in a context of scarce resource and budget constraints. It is imperative to get a better value for public expenditure in ALMPs. The last twenty years some meta-analysis focused on ALMPs efficiency and effectiveness has been presented; Martin (1998), Betcherman, Olivas and Dar (2004), Kluve (2010), Card, Kluve and Weber, (2010). A review connected with the Spanish performance and tourism activities is presented in this section.

Job searching assistance and counselling achieves positive impacts in the short run. This is the cheapest ALMP (Rosholm, 2014) but requires solid employment services. The effect can be limited when cyclical unemployment is high due an economic downturn or when informal economy avoids flourishing job offers.

Spain has the second OCDE worst average load rate of unemployed registered -269for each worker of the PES (OECD, 2014) which is an indicator of fragile employment services. Furthermore, Spain is above the average of informal economy in Eurozone with an estimation of $18.6 \%$ of national GDP (FEF, 2013). The informal economy is considered as comprising informal employment without secure contracts, benefits, or social protection either inside or outside informal enterprises (Eurostat, 2014).

The spatial distribution of placement services also appears as a key element of leaving unemployment (Détang \& Gaigné, 2009). Spain exhibits a strong spatial correlation between local unemployment rates and neighbourhoods which are other municipalities sharing boundaries points. The neighbourhood influences are important and spread unemployment so the spatial perspective cannot be ignored in the analysis of labour markets 
and economic activities (Pattaccini \& Zenou, 2007). The Spanish empirical evidence found important disparities in accessibility to employment offices that are affecting to the adequate delivering of ALMPs (Suarez et al, 2012a). Indeed, the market share of Spanish Public Employment Services is higher in the inner regions than coastal ones where labour market is more dynamic and the aggregate demand of tourism activities is higher. Not only it is a matter of professionals delivering ALMPs, but also it is the number of employment offices available and its spatial distribution (Suarez et al, 2012b).

Training programmes usually achieve more positive impacts in the medium and long run than in the short run (Arellano, 2010). Similar results were found in Balearic Islands using propensity score matching techniques (Alegre, 2010). The unemployed people who were trained in the low tourist season have $8.7 \%$ higher probabilities of being hired the next season than unemployed with same characteristics of gender, age, studies, nationality and professional experience but not involved in training activities. However, training programmes have risks such as the lock-in effect and the failure in the design of the programme due an inappropriate contents or the absence of quality management systems (CEDEFOP, 2015). Another issue is the unobserved heterogeneity. It is difficult to disentangle the overall effect of being treated by an ALMP from individual differences (Borra et al, 2012). As training programmes are longer than other ALMPs, motivation and personality traits may become relevant for the programme success.

Subsidized employment has not impacts in the employment outcomes of the participants in the long run. Furthermore, deadweight loss and substitution effects are presented in the literature (Verick, 2013). However, subsidized employment still captures the higher ratio of the Spanish ALMPs expenditure. The historical reason is to tackle labour market duality and promote open-ended employment. Figures are clear; 0.3\% of Spanish GDP is dedicated to subsidize employment (Cueto \& Suarez, 2014) but available evidences on effectiveness of subsidies for hiring are not positive. In Spain, the greatest effect of leaving unemployment through subsidized employment is 5\% (Kugler et al 2005).

On the other hand, subsidies targeted to facilitate transition from temporary to openended employment, only affect Spanish women between 30 and 45 years which have a higher probability of $8.6 \%$ to obtain an open-ended position than control group (Garcia \& Perez-Rebollo, 2009). This is a paradoxical employment policy in economies based on tourism because economic seasonal activities are incompatible with open-ended employment due the failure of productivity during low seasons.

Public employment programmes have not significant impact in improving the employability of the participants (Kluve, 2010). Indeed, from the point of view of many employers there is a stigma attached to participants (Betcherman et al, 2004). It is a social protection action used to counterbalance seasonal unemployment more than an employment policy. A clear example is the Spanish Plan E which created half million of temporary jobs in the whole country using a national fund scheme for local investments but the unemployment rate kept rocketing after Plan E. Public employment programmes should be transformed into training actions based on dual formation schemes that promote workers qualification and lifelong learning (Caparros, 2012).

Entrepreneurship Incentives have a positive effect in some unemployed groups such as older unemployed workers and well educated (Betcherman et al, 2004) but should be balanced 
with the business rate of survival. Spanish research is not conclusive due the lack of control group (Garcia Serrano \& Toharia, 2008). The degree of innovation and the entrepreneur's qualifications are key elements in terms of growing and business success. In 2008, the annual rate of business failure was 30\% similar to other Europeans countries (Cueto \& Suarez, 2014).

e-services are a new trend to provide ALMPs in some advanced economies (Martin, 2015). The empirical evidence is mixed about the usefulness of online tools as a labour market matcher but recent research suggest that online job searching might speed up the reemployment of unemployed workers (Kuhn, 2015). There is a trade-off between cost cutting expenditure and activation strategies that demands face-to-face techniques and meeting case (Rosholm, 2014). The Spanish Employment Service is developing a single online job board where can be matched national labour demand and labour supply. All regional Spanish PES are active part of this online job board.

On the other hand, SOIB is a full member of EURES network which provides guidance, job searching assistance and training across Europe. EURES network helps to allocate workers specialized in tourism activities during the winter season because Germany, Austria or Switzerland demand experienced workers with core competences as languages or customerorientation to match employment offers such as waiter, cook assistant or clean staff to cover vacancies related to snow tourism. From the point of view of the economies intensive in tourism, an strategic partnership among European employment services increases workers mobility and alleviates seasonal touristic unemployment between southern regions specialized in sun and beach and the central regions more focused on snow tourism.

Last but not least, the Council Recommendation on the integration of long-term unemployed into labour markets highlights the critical aspects to design better employment policies after a detailed analysis of ALMPs developed during the crisis (European Commission, 2015).

Single point of contact to services, measures and benefits: Germany, Denmark and Estonia have intensified PES interventions through single points of contact that offered permanent counselling and guidance by reducing the number of cases handled by counsellors and increasing contacts with jobseekers at least every four weeks. Results indicate a better transition to employment. The Berlin Job-Offensive is an example of monitoring closely unemployed with good results (Egenolf et al, 2013).

Better enforcement of benefits: Despite the mixed evidence about the conditional enforcement of benefits presented in the literature (Mc Vicar, 2014), there is room for better connectivity between job search and benefits policies. This is especially relevant for long-term unemployed, people with disabilities or other minorities. A pilot from the Netherlands reports how intensified contacts focused on rights and duties lead to higher job search intensity (Scharle, 2015).

Individualised support: There is widespread evidence in EU countries with different employment systems such as Germany, Netherlands, Luxemburg, Sweden, Portugal or Denmark that confirms how the combination of individualised support and monitoring outcomes has a positive impact. Regular meetings and individual action plans establishing a personalised integration pathway make a difference but the counsellor's caseload still is a critical variable (Eichorst et al, 2015). 
More employer engagement: European surveys indicate the lack of commitment of many enterprises with public employment services and unemployment in different countries (Rakies \& Davies, 2015). Employers differentiate between candidates on the basis of length of time they have spent out of work. However, the effectiveness of ALMPs depends on employer participation. Personalised interventions with employer involvement have registered positive re-employment effects in Austria, Sweden and Germany (European Commission, 2015). It is not only a matter of subsidizing employment but also of designing training actions or guidance schemes among employment services, employers needs and other stakeholders cooperatively.

To sum up, it is high time to invest in a fresh generation of tailored ALMPs that respond closely to the idiosyncratic economy of the territories and aligned with the empirical evidences.

\section{EMPLOYMENT SERVICES AND POLICIES IN BALEARIC ISLANDS}

As chapter two indicates, Balearic Islands labour market points a better employment, activity and unemployment rates than Spain and East Spain. Notwithstanding, data also indicate a pattern of labour market dysfunctionalities which are linked with economies highly specialized in tourism and lately with the unexpected effects of Spanish labour market reform executed in 2012.

The major key facts of tourism impact in Balearic Islands labour market (Govern Illes Balears, 2015):

- Temporality: $90 \%$ new contracts were temporary.

- Partiality: $40 \%$ new contracts signed were part-time.

- Instability: labour rotation index (contracts / persons employed) was 1.91 .

- Low wages: Balearic Islands average wage is $€ 1,776$ monthly and 50\% of workers earn less than $€ 1,000$ while EU 28 countries average wage $€ 2,026$.

- Human capital: $70 \%$ of Balearic Islands labour force only attained a basic or intermediate educational level.

- Informal economy: 106 workers have been located without formal contracts during ordinary summer inspections by the Social Security. The volume of fines for Informal economy amounted $€ 350,000$.

- Lack of investment in technologies: Balearic Islands expenditure in $\mathrm{R}+\mathrm{D}$ is less than 0.5\% Regional GDP while EU 2020 Strategy recommends at least 3\%.

- High pressure on natural resources because more than 13 million visitors spent their holidays in the Balearic Islands with an average stay of 5.5 nights per visitor in 2014.

\subsection{Balearic Islands Employment Service (SOIB)}

SOIB is the public body entitled to design, execute, monitor and assess ALMPs in the Balearic Islands. It is an official representative in the Spanish Conference of Labour Affairs and institutional provider of SISPE, which is the national database to register, management and monitoring labour market policies. 
Law 7/2000 on SOIB regulates the composition, functions, procedures and resources. It is enacted that SOIB competences are registered unemployment, underemployment and labour contracts, job searching assistance, management of vacancies, counselling and guidance, Vocational Education Training (VET), dual training, apprenticeships, work-based learning, public employment, subsidizing employment, entrepreneur assistance, EURES network in Balearic Islands and ALMPs statistics.

From the point of view of the registered unemployed, SOIB manages a set of ALMPs in terms of individual roadmap. It means a personalised service that may includes counselling, training, job searching assistance or public employment programmes with the purpose of increasing worker's skills and the probabilities of being hired by firms.

From the point of view of the enterprises, SOIB offers a free service of managing vacancies and specialized support using other institutional stakeholders which can provide knowhow or fundraising.

Main premises are 2 training centres and 13 employment offices proportionally distributed by population among Majorca, Minorca, Ibiza and Formentera. SOIB regular staff is 283 workers and budget was EUR 43 million in 2014.

\subsection{Balearic Islands Employment Plan (POIB)}

This is the steering guide to execute ALMPs in the islands and the policy option to address weaknesses of the labour market. POIB is articulated under the particularities of an economy intensive on services with a high variability of unemployment and employment rates caused by the seasonality of the tourism activities and the business structure formed by microenterprises. It is focused on four areas:

Improving the employment: better matching between labour supply and labour demand, focusing on economic activities with high employment growth potential such as suggested by the economy colours; green (sustainable economy), silver (ageing economy) and blue (maritime economy).

More employment, quality and stability: Encouraging the transformation of temporary contracts into permanent ones. Promoting the conversion of part-time contracts into fulltime. Fostering in the culture of the compliance and updating workers skills through VET.

Inclusive employment: developing guidance services that help workers at risk, subsidising employment for long-term unemployed, youth and female. Offering apprenticeships and dual training schemes for low skilled youth.

More entrepreneurships: entrepreneur culture promotion, collaboration with other public bodies to simplify requirements to start up a business, creation of entrepreneur awards and opening an entrepreneur subsidy line.

\subsection{Specific issues of the employment protection legislation in tourism labour markets}

Balearic Islands contractual arrangements and the employment protection legislation are covered by the Spanish workers Statute 2/2015 but the impact of tourism activities has produced specific legal arrangements targeted to tourism labour force. A clear example is the fijo-discontinuo contract. This is a non-standard employment launched in the 
nineties with the aim of offering some protective legal scheme to seasonal workers. It is an intermittent and open-ended contract because assures that workers are going to work every summer in the same business because there is a mandatory recall or the employer would be severely penalised at the beginning of the tourism season. Despite the fact that workers under fijo-discontinuo schemes are unemployed and receiving benefits during the winter season, they are not interested in active labour market policies as they have a legal commitment of formal employment in the next summer season. More than 45,000 Balearic Islands workers are under the fijos-discontinuos contracts and this is a great challenge in terms of policy action as their high expectations and reservation wage are a serious disincentive to participate in employment programmes.

\section{METHODOLOGY}

\subsection{Databases}

Two major databases were used to cover the study;

SISPE which is the Spanish central database designed to provide administrative traceability of grants, subsidies, unemployment benefits, training courses, employment offered, job searching assistance, guidance and other actions to boost the employability of the workers.

Contracts registered which is the Spanish central database to manage information about workers being hired, typology of employments and labour market dynamics.

\subsection{Results}

5.2.1. SOIB function of registering labour contracts and unemployment

\section{Graph 19 \\ LONG RUN RELATIONSHIP BETWEEN LABOUR \\ CONTRACTS AND UNEMPLOYMENT}

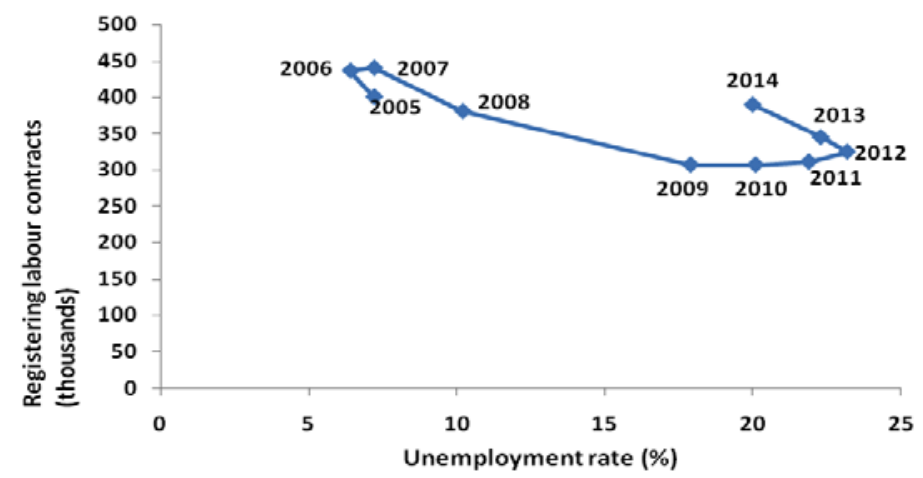

Source: Spanish contracts registered and Eurostat. 


\section{Graph 20}

\section{REGISTERING LABOUR CONTRACTS}

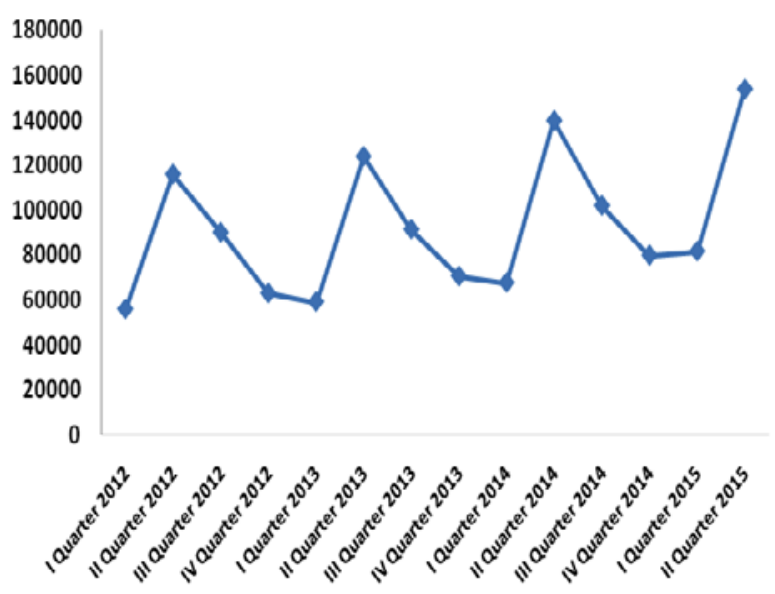

Source: SOIB.

\section{Graph 21 \\ UNEMPLOYMENT RATE TREND LINE}

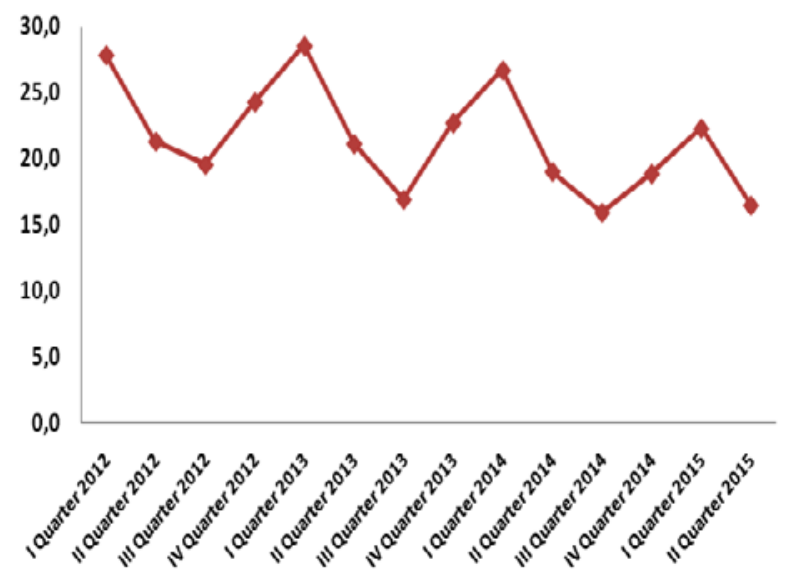

Source: Spain LFS.

Registering labour contracts includes all contracts signed in compliance with law. Graph 19 shows the relationship between total contracts during one year and unemployment rate seasonally adjusted. One specific feature of the Balearic Islands labour market is temporality which means that if workers want to be employed all the time, they have to sign several contracts per year. 
Another recent feature is partiality. Many workers need two or three employments at the same time to obtain a minimum income due low wages or because the employment offered is partial-time. This is especially relevant in economic activities such as food, accommodation and retails. Both situations may explain how a steady increment of labour contracts does not provoke a deeper reduction on unemployment rate from 2012 to 2014 .

Graph 20 shows how the Balearic Islands labour market is depending on the summer tourist season because labour contracts are mainly concentrated in the second and third quarter of the year. Consequently, the unemployment rate trend line decreases in the same quarters as showed in graph 21 .

The number of contracts and unemployment rate indicate some effects of the Spanish labour market reform executed in 2012. Graph 19 shows a steady increase in labour contracts but a smaller decrease of unemployment rates. In 2012 the number of contracts registered by SOIB was 325,000 and unemployment rate was $23.2 \%$ but in 2014 contracts were 390,000 and unemployment rate dropped just to $20 \%$. However, in 2008 -before the reform- the unemployment rate was only $10.2 \%$ with a similar figure of contracts registered $(381,000)$ than in 2014. An explanation is the change in the typology of contracts. Nowadays, $90 \%$ of the new contracts are temporary and $40 \%$ partial-time (Govern de les Illes Balears, 2015). So the Spanish labour market reform has been focused on providing more flexibility for hiring and firing but it has produced unexpected effects such as underemployment an inequality.

Finally, the evolution of contracts along the years shows the dependency of tourism activities and the seasonality of labour market. Summer months are the most contracted while winter months are counterfactuals, such transitions have an effect in unemployment rate that pushes to execute many ALMPs such as training and guidance mainly during the low season.

\subsubsection{Job searching assistance and management of vacancies registered}

Table 5

\section{SOIB JOB SEARCHING ASSISTANCE AND MATCHING MAGNITUDES IN 2014}

\begin{tabular}{|r|r|}
\hline Registering labour contracts by SOIB & 390,000 \\
\hline Jobseekers registered in SOIB and obtaining one or more labour contracts & 241,754 \\
\hline Jobseekers registered in SOIB, receiving ALMPs and obtaining a labour contract & 112,723 \\
\hline Employment offer managed by SOIB & 2,956 \\
\hline Vacancies managed by SOIB & 5,320 \\
\hline Vacancies offered by SOIB and matched with jobseekers registered in SOIB & 4,020 \\
\hline Average of vacancies by employment offer & 1.8 \\
\hline Matching ratio between jobseekers registered and vacancies managed by SOIB & $75.56 \%$ \\
\hline Enterprises offering an employment offer to SOIB & 1,722 \\
\hline Enterprises registering labour contracts & 43,278 \\
\hline Enterprises ratio using SOIB for matching employment offers and candidates & $3.98 \%$ \\
\hline Average of registered contracts by an enterprise & 9.01 \\
\hline
\end{tabular}

Source: SISPE 
Employment offers $(2,956)$ and vacancies $(5,320)$ managed by SOIB is extremely low if you compare with total labour contracts $(390,000)$. However, the matching rate between jobseekers registered and vacancies managed by SOIB is $76 \%$ which means that SOIB is efficient in matching the jobs and candidates. More effort should be done in capturing new vacancies because enterprises rate using SOIB as a source to solve its human resources needs is less than $4 \%$.

\subsubsection{Counselling and guidance}

SOIB uses a counselling methodology that includes three levels:

Fast Counselling: It is designed for jobseekers with a high profile of employability which means that they only need simple actions such as professional information about employment and self-employment, job vacancies recommended and quick feedback on professional targets and economic activities that are demanding labour.

Medium Counselling: It is designed for jobseekers with some professional weaknesses. It always includes an employability diagnosis and a professional roadmap with targets and milestones. The dimensions affected are professional experience, education, training and competences acquired along professional career. The aim is to promote changes that increases their probability of being hired taking into account the labour market trends. Not only are included activities from fast counselling but also are workshops about how to prepare a $\mathrm{CV}$, how to deal with an online selection process or a face to face interview, how to look for an employment offer, European mobility and VET recommendations.

Deep Counselling: It is designed for jobseekers with important professional deficits or unemployed at-risk such as long-term unemployed, NEET youth, migrants or disabled workers. It is an intensive employment roadmap as consequence of the mandatory activation of jobseekers entitled to national benefits such as PREPARA. It means a monthly relationship between unemployed and counsellor. Both share an employment roadmap and the unemployed must accomplish some activities that are considered proof of looking for a job actively. It include activities from the previous guidance levels plus long-term actions such as training. If a jobseeker meets the milestones assigned to his professional roadmap, he will have preference in vacancies, public employment programmes and other ALMPs.

Table 6

SOIB COUNSELLING MAGNITUDES IN 2014

\begin{tabular}{|r|r|r|}
\hline & \multicolumn{1}{c|}{$\mathbf{N}^{\mathbf{0}}$} & \multicolumn{1}{c|}{$\%$} \\
\hline NOT INVOLVED IN COUNSELLING & 40,999 & 16.77 \\
\hline FAST COUNSELLING & 104,271 & 42.64 \\
\hline MEDIUM COUNSELLING & 44,664 & 18.26 \\
\hline DEEP COUNSELLING & 54,602 & 22.33 \\
\hline JOBSEEKERS & 244,986 & 100 \\
\hline
\end{tabular}

Source: SISPE. 


\section{Graph 22 \\ SOIB COUNSELLING SERVICES IN THE LONG RUN}

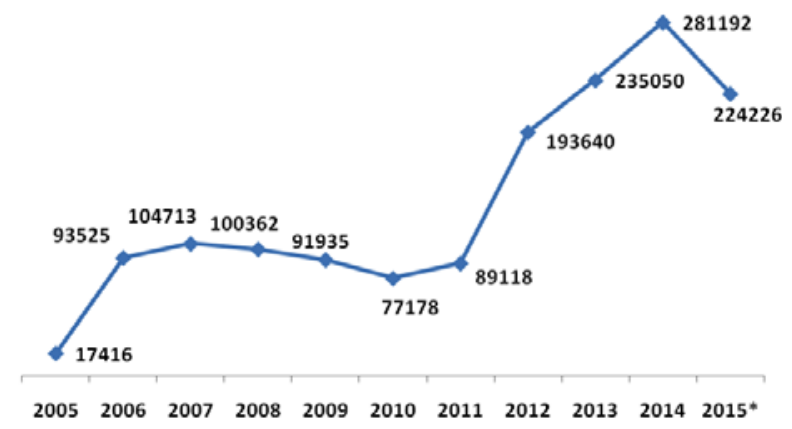

Source: SISPE.

Counselling and career guidance are the most productive services in SOIB. Almost $83 \%$ of jobseekers registered have received at least one counselling service during 2014 . SOIB is more focused on fast counselling $(42.56 \%)$ than medium $(18.23 \%)$ or deep counselling (22.29\%).

Results are in line with the fact that vacancies are more concentrated in the second and third quarter of the year due the tourism seasonality. Such employment peak is a disincentive to be involved in long term professional roadmaps unless jobseekers are really at-risk and do not obtain employment in summer.

Finally, graph 21 shows how counselling services have tripled until 281,192 once the debt crisis erupted in 2011 and the Spanish labour market reform was approved.

5.2.4. Vocational Education Training, dual training, and apprenticeships

Table 7

SOIB VOCATIONAL EDUCATION TRAINING MAGNITUDES IN 2014

\begin{tabular}{|r|r|}
\hline \multicolumn{3}{|c|}{ EMPLOYMENT AND LIFE LONG LEARNING } \\
\hline Unemployed having VET contracts based on dual schemes (training+working) & 1,848 \\
\hline Unemployed receiving training & 12,498 \\
\hline Employed receiving training & 794 \\
\hline Unemployed receiving work-based learning & 196 \\
\hline VET courses executed & 864 \\
\hline VET organizations involved & 314 \\
\hline Professional experience certified and equivalent to Educational qualifications & 910 \\
\hline
\end{tabular}

Source: SOIB. 


\section{Graph 23 \\ VOCATIONAL EDUCATION TRAINING IN 2014}

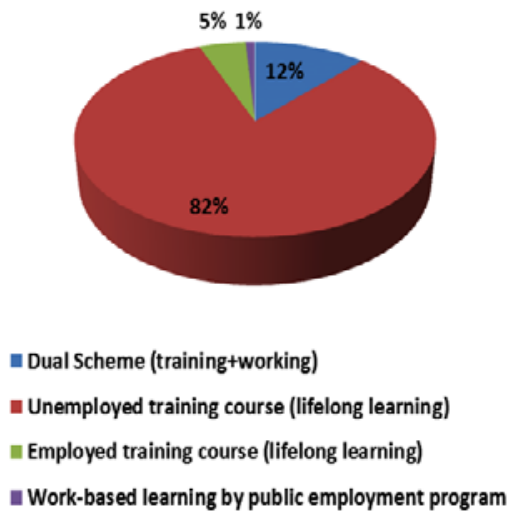

Source: SOIB.

Graph 24

VOCATION EDUCATION TRAINING IN THE LONG RUN

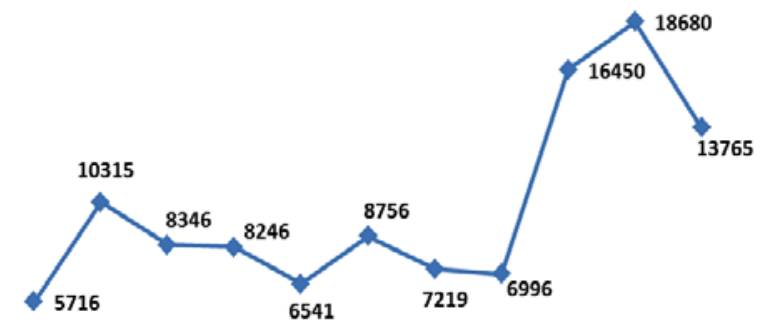

$20052006200720082009201020112012 \quad 2013 \quad 2014 \quad$ 2015* $^{*}$

Source: SISPE.

Training actions designed for employed and unemployed are the most important VET policy executed by SOIB (87\%) because is the key element to fight against the low level of human capital. Indeed, VET is the suitable intervention to redesign a professional career based on tourism activities and move from seasonal employment to other more permanent. Dual schemes and work based programmes are less frequent but they are part of training catalogues that should be increased in line with the European policy recommendations. Another challenge is to increase VET quality in terms of organizations certified in Quality management (30\%) and courses certified by the Employment Ministry (74\%). Finally, 1,848 VET contracts are offering tailored training solutions for unemployed while they are working and learning in enterprises. 
Graph 24 shows how VET has the same trend than counselling services in the long run and confirms how Balearic Islands develop ALMPs as a human resources conjuncture policy dependent on economic performance and unemployment rates more than a permanent policy to boost human capital and create the basis to shift from an intensive economy based on tourism to another one more sustainable.

5.2.5. Public employment programmes and subsidising employment

\section{Graph 25 \\ PUBLIC EMPLOYMENT IN THE LONG RUN}

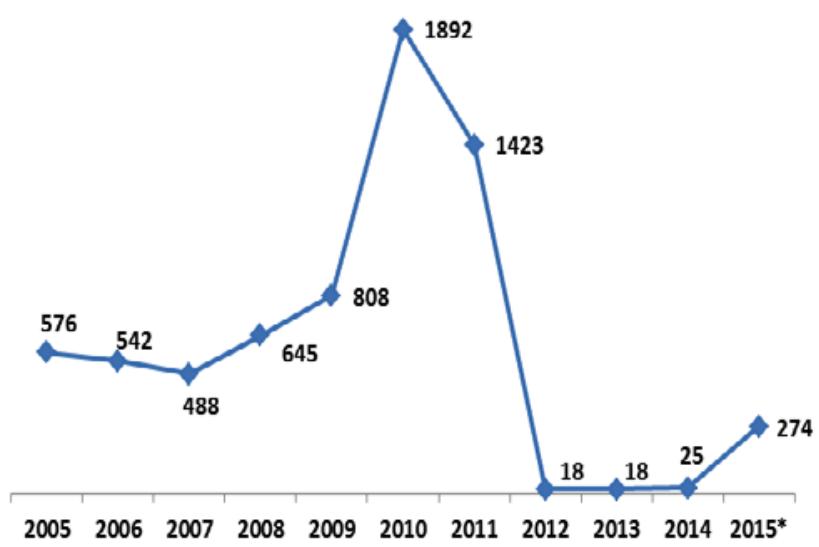

Source: SISPE.

\section{Graph 26 \\ EMPLOYMENT SUBSIDY IN THE LONG RUN}

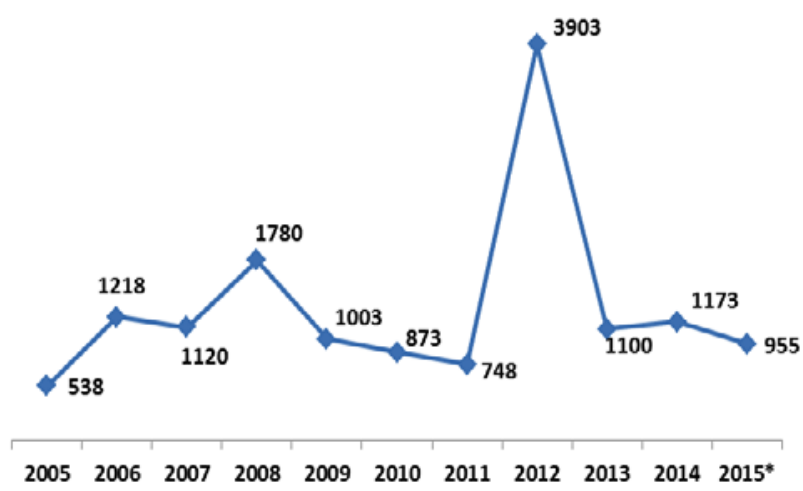

Source: SISPE. 
Public employment programmes are the most expensive ALMP. It was a common employment policy during the first part of the crisis because it enhances labour market output while covers socials or environmental needs. However, Spain suffered a bank bailout in 2012 and the national government requested all public administrations to cut spending on social, health and employment policies in order to reduce deficit. Consequently, SOIB has reduced public employment programmes to minimum during the second part of the economic downturn.

SOIB subsidizes employment with specific groups such as disabled, victims of gender violence and youth at-risk. Other general employment subsidies are managed by Spanish Employment Service. In fact, data shows that number of subsidized employment beneficiaries is fairly stable, except in 2008 and 2012. Reason was that subsidies were extended to long-term unemployed.

\subsubsection{Entrepreneur Assistance}

Table 8

SOIB ENTREPRENEUR MAGNITUDES IN 2014

\begin{tabular}{|r|r|}
\hline New entrepreneurs assisted by SOIB & 4 \\
\hline New entrepreneurs & 5,315 \\
\hline Cooperatives created & 15 \\
\hline Enterprises created & 2,887 \\
\hline Social economy ratio in new enterprises launched & $0.005 \%$ \\
\hline
\end{tabular}

Source: SISPE.

\section{Graph 27}

SOIB ENTREPRENEUR SERVICES IN THE LONG RUN

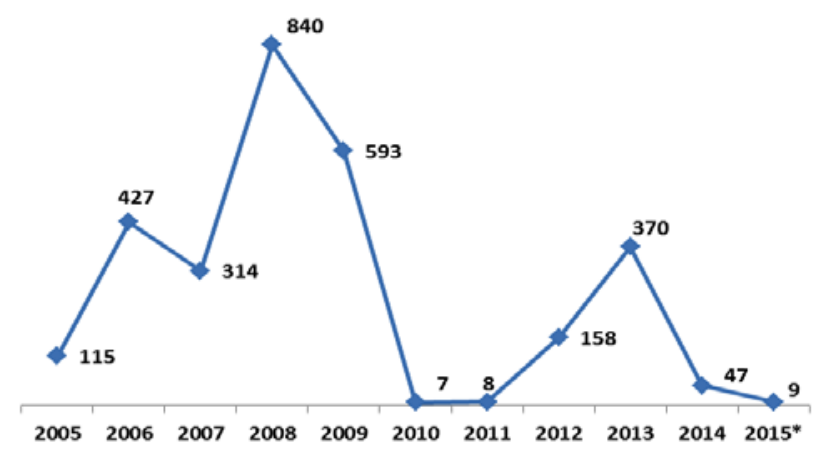

Source: SISPE. 
Entrepreneur services are the most important weakness in the SOIB functions. Only 4 entrepreneurs were helped by SOIB while 5,315 new entrepreneurs started in 2014. Despite the fact that entrepreneur assistance requires a high specialized service, SOIB should develop a strategy to offer its services and become a relevant stakeholder in the Balearic Islands entrepreneurship system.

The erratic evolution of the entrepreneur services suggest that has not been an employment policy priority for SOIB. Some reasons are the complexity required to launch a comprehensive entrepreneur support service, the existence of other public bodies promoting self-employment and the influence of the economic perception when somebody is deciding to be self-employed.

\section{CONCLUDING REMARKS}

The Balearic Islands economy is characterized by service activities (86.17\%), microenterprises $(86.16 \%)$ and the seasonality of productivity but the archipelago overcomes better the economical downturns than Spain, East Spain and European Union.

However, Balearic Islands do not invest in human capital neither in $\mathrm{R}+\mathrm{D}$. The low rate of tertiary education $(27 \%)$, the extreme rates of early leavers $(32 \%)$ and the lack of investment in research $(0,5 \%$ GDP) are symptoms of an economic model based on low productivity and precarity. Indeed, a detailed look of labour market shows periodic oscillations of the unemployment rate higher than $10 \%$ when you compare the summer and winter quarter. Such dynamics discourages labour force to participate in VET processes because the Balearic Islands labour market periodically supplies a summer peak of low qualified vacancies. The whole picture indicates a tourism economy based on a mature destination of sun and beach services

Acting as a counter, SOIB smoothes the sharpened transitions between employment and unemployment by offering a classic package of ALMPs. The aim is to promote the reemployment of unemployed and comply the legal activation principle that promotes professional support with unemployed workers who are receiving a benefit. The counseling services cover major part of registered unemployment $(83 \%)$ but the intensity and frequency varies widely among unemployed. A third of unemployed registered who received ALMPs (29\%) during 2014 obtained a contract the same year but it cannot be established causality because the aim of the study was to present a statistic panorama and not an impact evaluation.

The employment offers managed by SOIB is extremely low $(1,4 \%)$ from total contracts registered in 2014 while the matched vacancies ratio is good enough $(76 \%)$ which means that more structure is required to capture more vacancies and to match enterprise needs. It would be a great improvement due the effective process used by SOIB in managing vacancies.

VET is a key tool to boost human capital and SOIB should evolve from a training services based on traditional courses $(82 \%)$ to new tailored solutions such as dual schemes and work-based actions that only capture a small part of the total training output $(18 \%)$. 
Entrepreneur services are part of SOIB functions but the entrepreneurs helped are almost zero. Any improvement would be welcomed. Furthermore, an institutional approach is required to increase the SOIB interest in the demand side. Some initial actions can be a deep diagnosis of microenterprise needs, fundraising support and more cooperation in matching human resources.

SOIB always uses subsidized employment to promote disabled workers and other specific groups. The challenge is transforming subsidized employment into normal one and do not promote artificial employment. A design of phasing out subsidies and a permanent monitoring to see if recipients are maintained would be convenient if SOIB wants to analyze the real impact of subsidizing unemployment in the long run.

SOIB public employment programmes depend on political and economic circumstances. A redefinition is required due the high cost associated, the labour market dynamics and the lack of coordination with other ALMPs such as counselling or job search. It is better to turn it into dual training schemes.

e-services are a new horizon to explore in ALMPs, practical experiences such as the EURES website are good attempts but still have to be assessed. Furthermore, SOIB only uses the ICT as a communication way with unemployed rather than an interactive way to match labour supply and demand.

\section{GENERAL RECOMMENDATION}

Tourism is the major source of revenues in Balearic Islands economy but the annual velocity of unemployment and employment for many Balearic Islands workers has promoted a political vision of ALMPs as a palliative policy instead of an opportunity to invest in human capital and readdress the undesirable effects of an economy intensive in services. Some changes should be done by designing a new economic strategy and tailoring a new generation of ALMPs that take into account the diversity of the unemployment and the EU recommendations. It means more analysis on key variables that are affecting the success of the employment and, above all, to develop a long term action to evolve towards an economy with more productivity and equity.

\section{BIBLIOGRAPHY}

ALEGRE, J. (2010): «Valoració de l'efecte sobre la inserció laboral dels cursos de formació professional dirigits a persones en atur». Estudis Laborals OTIB, $\mathrm{n}^{\circ}$ 9, pp. $1-75$.

ARELLANO, F.A. (2010): «Do training Programmes get the unemployed back to work? A look to Spanish Experience». Revista de economia aplicada. $\mathrm{n}^{\circ}$ 53, pp. 39-65.

BETCHERMAN, G., OLIVAS, K.; DAR, A. (2004): «Impact of ALMPs: new evidence from evaluations with particular attention to developing and transition countries». World Bank Social Protection Discussion Paper, $\mathrm{n}^{\circ} 0402$.

BORRA, C.; PALMA, L.; GONZALEZ, M.C.; AGUADO, L.F. (2012): «Evaluation of ALMPs in a context of high unemployment», Desarrollo y Sociedad, $\mathrm{n}^{\circ} 70, \mathrm{pp}$. 93-115. 
CARD, D.; KLUVE, J.; WEBER, A.: (2010): “ALMPs evaluations: A meta-analysis». Economic Journal, $\mathrm{n}^{\circ}$ 129, pp. 452-477. Available at: http://eml.berkeley.edu/ card/ papers/card-kluve-weber-EJ.pdf

CAPARROS, F. (2012): «Les Escoles Taller, Cases d'Ofici i els Tallers d'Ocupació: un quart de segle de formació amb alternança amb l'ocupació (1985-2011): valoració i propostes de futur». Journal of Public Policies and Territories P3T, $\mathrm{n}^{\circ} 2$, pp. 1-33. Available at: http//www.politicsandterritories/ETCOTO.pdf

CUETO, B.; SUAREZ, P. (2014): «A review of active and passive labour market policies in Spain». MPRA Paper, $\mathrm{n}^{\circ}$ 60648, pp. 1-35.

DÉTANG-DESSENDRE, C.; GAIGNÉ, C. (2009): «Unemployment duration, city size, and the tightness of the labour market». Regional Science and Urban Economics, n 39 , pp. 266-276.

EGENOLF, D.; FERTIG, M.; HUNGER, K.; PUXI, M.; ROSEMANN, M.; WEIMANN, M. (2013): Implementationsstudie zur Berliner Joboffensive. Kholn: ISG GmbH.

EICHORST, W.; NEDER, F.; TOBSCH, V.; WOZNY, F. (2015): «A European Perspective on Long-Term Unemployment». Iza World of Labor, Discussions Series, $\mathrm{n}^{\circ}$ 9321, Available at: http://ftp.iza.org/dp9321.pdf

EUROPEAN UNION. CEDEFOP (2015): Stronger VET for better lives: Cedefop's monitoring report on VET policies 2010-2014. Luxemburg: Publications Office of the European Union.

EUROPEAN UNION. COMMISSION (2003): «Recommendation 2003/361/EC of 6 May 2003, concerning the definition of micro, small and medium-sized enterprises». Official Journal of the European Union, L124, pp 36-42.

EUROPEAN UNION. COMMISSION (2015) «Analytical supporting document accompanying the proposal for a Council Recommendation on the integration of the longterm unemployed into the labour market» Luxemburg: Publications Office of the European Union, SWD(2015) 176.

EUROPEAN UNION. EUROSTAT (2013): Labour Market Policy Statistics. Methodology 2013. Eurostat Manual and Guidelines. Luxemburg: Publications Office of the European Union.

EUROPEAN UNION. EUROSTAT (2014): Essential SNA: Building the basics 2014. Eurostat Manual and Guidelines. Luxemburg: Publications Office of the European Union

EUROPEAN UNION. EUROSTAT (2014): Eurostat Regional yearbook 2014. Statistical books. Luxemburg: Publications Office of the European Union

GARCIA-SERRANO; C., TOHARIA, L. (2008): Evaluación del programa de capitalización de las prestaciones por desempleo en España, 1986-2007. Madrid: Ministerio de Trabajo.

GARCIA PEREZ, J.I; REBOLLO, Y. (2009): «The use of permanent contracts across Spanish regions: do regional wage subsides work?»Investigaciones Económicas, $\mathrm{n}^{\circ}$ 23, pp. 97-130.

JIMENEZ-FERNÁNDEZ, A.; MARTINEZ-PARDO R. (2013): «La economía sumergida en España». nº 4, Madrid: Fundación Estudios Financieros. 
KUGLER, A.; JIMENO, J.; HERNANZ, V. (2002): «Employment Consequences of Restrictive Employment Policies: Evidence from Spanish Labour Market Reforms». Iza World of Labor, Discussions Series, $\mathrm{n}^{\circ}$ 657, Available at: http://ftp.iza.org/dp657. pdf

GOVERN DE LES ILLES BALEARS (2015): Pla d'ocupació de les Illes Balears 20142017. Mallorca: Servei de publicacions de la CAIB.

INTERNATIONAL LABOUR ORGANIZATION (2014): Spain: Growth with employment 2014. Studies on growth with equity. Geneva: Publications Office of the International Labour Organization.

INTERNATIONAL LABOUR ORGANIZATION (2014): Skills mismatch in Europe. Statistics brief. Geneva: Publications Office of the International Labour Organization.

KLUVE, J. (2010): «The effectiveness of European ALMPs». Iza World of Labor, Discussions Series, $\mathrm{n}^{\circ}$ 2018, Available at: http://ftp.iza.org/dp2018.pdf

LECHNER, M.; WUNSCH, C. (2009): «Are training programmes more effective when unemployment is high?» Journal of Labor Economics, $\mathrm{n}^{\circ} 27$, pp. 653-692.

MANERA, C. GARAU, J. SERRANO, E. (2016): «The evolution and impact of tourism in the mediterranean: the case of island regions, 1990-2002», Cuadernos de Turismo, $\mathrm{n}^{\circ} 37$, pp. 269-303.

MARTIN, J. (1998): What Works among ALMPs: Evidence from OECD Countries' Experiences, OECD Labour Market and Social Policy Occasional Papers, n ${ }^{\circ} 35$, OECD Publishing.

MARTIN, J. (2015): «Activation and ALMPs in OECD countries: stylised facts and evidence on their effectiveness», Iza World of Labor, Policy Series, n 44, Available at http://ftp.iza.org/pp84.pdf

MCVICAR, D. (2014): «The impact of monitoring and sanctioning on unemployment exit and job-finding rates». Iza World of Labor, n 49, Available at http://wol.iza. org/articles/impact-of-monitoring-and-sanctioning-on-unemployment-exit-and-jobfinding-rates-1.pdf

OECD (2014): Economic survey of Spain. Paris: Publications Office of the Organization for Economic Cooperation and Development.

PATACCHINI, E.; ZENOU, Y. (2007): «Spatial dependence in local unemployment rates». Journal of Economic Geography, n 7, pp. 169-191.

RAKIES, L.; DAVIES, B. (2015): European Employers' perspectives on long-term unemployment, recruitment and public employment services. London: Institute for Public Policy Research Available at: http://www.ippr.org/files/publications/pdf/ employers-perspsectives-long-term-unemployment_May2015.pdf?noredirect=1

ROSHOLM, M. (2014): «Do case workers help the unemployed? Evidence for making a cheap and effective twist to labor market policies for unemployed workers». Iza World of Labor, $\mathrm{n}^{\circ} 72$, Available at: http://wol.iza.org/articles/do-case-workers-helpthe-unemployed.

SALVÀ TOMÀS, P. (1998): «Los modelos de desarrollo turístico en el Mediterráneo», Cuadernos de Turismo, $\mathrm{n}^{\circ} 2$, pp. 7-24. 
SCHARLE, Á.; BALÁZS, V.; FLORA, S. (2015): «Policy Convergence across Welfare Regimes: The Case of Disability Policies». WWWforEurope, Working Papers series, $\mathrm{n}^{\circ} 76$.

SPAIN. INSTITUTO NACIONAL DE ESTADISTICA (2015): Anuario Estadístico de España 2015. Madrid: Instituto Nacional de Estadística.

SUAREZ, P.; MAYOR, M.; CUETO, B. (2012a): «The accessibility to employment offices in the Spanish labor market». Papers in Regional Science, $\mathrm{n}^{\circ}$ 91, pp. 823-848.

SUAREZ, P.; MAYOR, M.; CUETO, B. (2012b): «La eficiencia de los servicios públicos de empleo en España en un escenario descentralizado: Un análisis desde la perspectiva de la oferta». Estudios de economía aplicada, $\mathrm{n}^{\circ}$ 30, pp. 1-22.

VERICK, S. (2013); «Labour Market Policies for Development» in Perspectives on Labour Economics for Development. Geneva: Publications Office of the International Labour Organization pp. 246-277. 